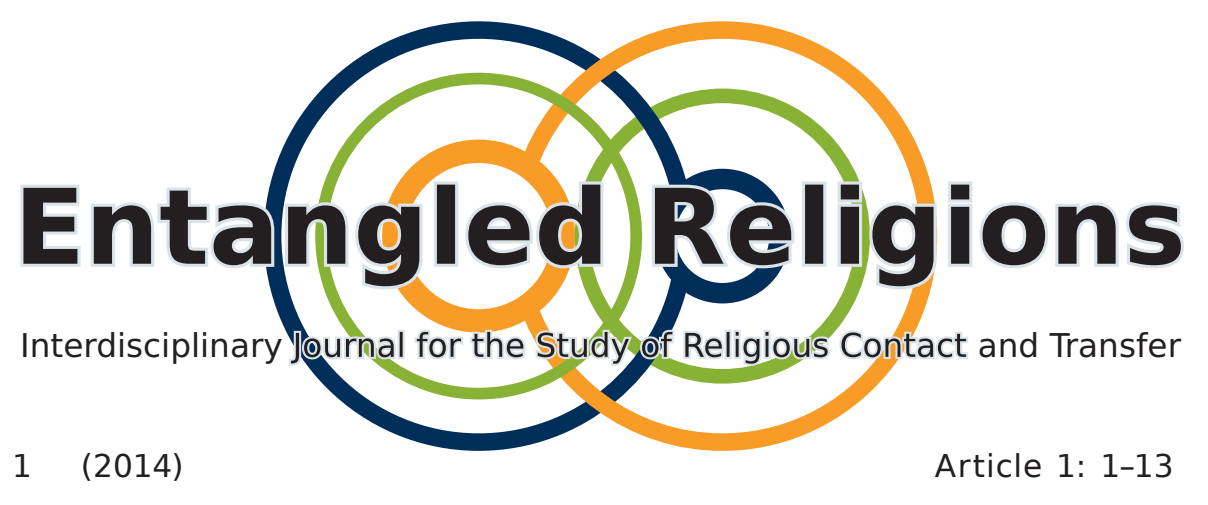

\title{
Editorial
}

\section{Welcome to Entangled Religions!}

VIVIAN STROTMANN

Ruhr-Universität Bochum, Käte Hamburger Kolleg "Dynamics in

the History of Religions between Asia and Europe", Germany

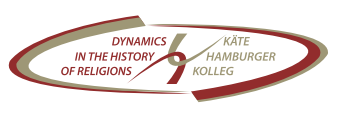




\section{Editorial}

\section{Welcome to Entangled Religions!}

VIVIAN STROTMANN

Ruhr-Universität Bochum

For more than six years, the Käte Hamburger Kolleg "Dynamics in the History of Religions between Asia and Europe" (KHK) has served as a focal point for scholars from all over the world.

As part of the Center for Religious Studies Research Department (CERES) at Ruhr-University Bochum, the KHK has offered financial support and practical means, as well as an academically diverse and productive environment to researchers examining questions of religious contact and transfer from the first millennium C. E. to the present day.

Since 2008, CERES/KHK has hosted more than 120 workshops, lectures and symposia by and for scholars from all academic fields. The KHK takes pride in having invited more than 70 international Visiting Fellows, whose diverse academic and personal backgrounds have contributed to and shaped the interdisciplinary and multifaceted research conducted and published over the past six years.

Recently, these efforts have been assessed by our sponsor-the German Federal Ministry of Education and Research-and have been found worthy of renewed funding with the amount of app. 8.5 million euros over the next four years.

During these coming years, the KHK will continue its work - and will take it one step further: We are not only bringing scholars to Bochum. Now, we are reaching out to you! 
This is why the KHK has established its online journal Entangled Religions - Interdisciplinary Journal for the Study of Religious Contact and Transfer (ER).

Why exactly?

- For quality: $E R$ is peer-reviewed by handpicked experts.

- For diversity: $E R$ is open to scholars from all disciplines.

- For innovation: $E R$ presents latest cutting-edge research.

- For comprehensiveness: ER encourages definitory and methodological debate that allows experts from different fields to profit from your findings.

- For range: $E R$ can be accessed under the open access license all over the world. Its use of DOIs ensures that your research remains accessible internationally.

In short: It's the place to publish.

We are looking forward to receiving your contributions! 


\section{Entangled Religions -The Editorial Board}

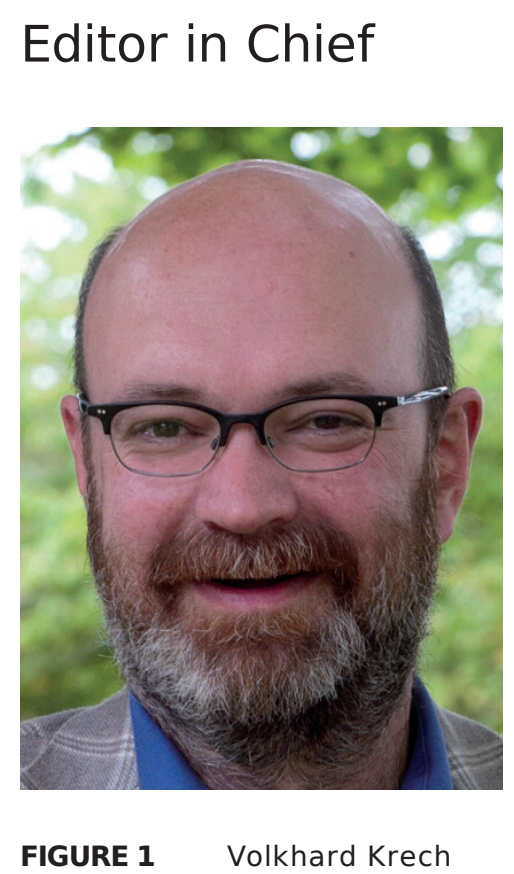

Volkhard Krech, is professor of Religious Studies at Ruhr-University Bochum, director of the Käte Hamburger Kolleg “Dynamics in the History of Religions between Asia and Europe" and director of the Center for Religious Studies Research Department (CERES).

His research focuses on the theory of religion and history of religions, religious pluralization and globalization, and processes of sacralization. Volkhard Krech also researches phenomena of religion and violence, religion and art, and has a particular interest in the history of Religious Studies. 


\section{Managing Editor}

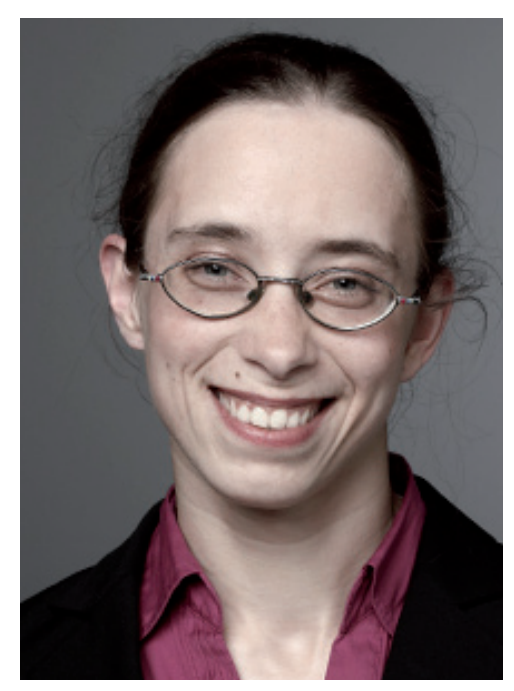

FIGURE 2 Vivian Strotmann

Vivian Strotmann studied Middle Eastern Studies/Islamic Studies and English at Ruhr-University Bochum and at the National University of Ireland, Maynooth (Co. Kildare). She conducted research in Egypt and Yemen and wrote her Ph.D. thesis on Majd al-Dīn al-Fīrūzābādī. Her research focuses on the history of sciences (with a particular interest in Arabic lexicography and Islamic philosophy), on networks and on the migration of knowledge between countries and cultures.

Vivian Strotmann taught in and outside of university and worked as a translator. For several years, she served as Editorial Assistant to The World of Islam/International Journal for the Study of Modern Islam (published with Brill). In June 2014, she joined the Käte Hamburger Kolleg “Dynamics in the History of Religions between Asia and Europe“ as Managing Editor of Entangled Religions. 


\section{Editorial Board}

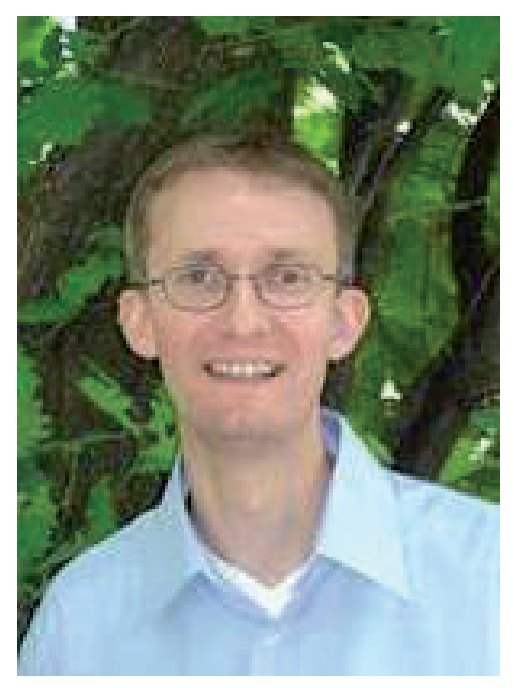

FIGURE 3 Andreas Bendlin

Andreas Bendlin is Professor of Classics at the University of Toronto. He earned his Ph.D. in Ancient History from the University of Oxford in the United Kingdom and a habilitation in Religious Studies from the University of Erfurt. He has held research fellowships at the Universities of Oxford, at Ruhr-University Bochum, and at the University of Constance.

Andreas Bendlin's research and publications focus on ancient religion. He has a particular interest in the pragmatics of religious life in the Roman Mediterranean. He also works and publishes on Roman social history, with a particular emphasis on the life of associations in the Graeco-Roman world; and on Roman literary and cultural history. Current research includes a large-scale project on demography, migration, and urbanism, and their impact on religious pluralism in the Roman world. (A. Bendlin) 


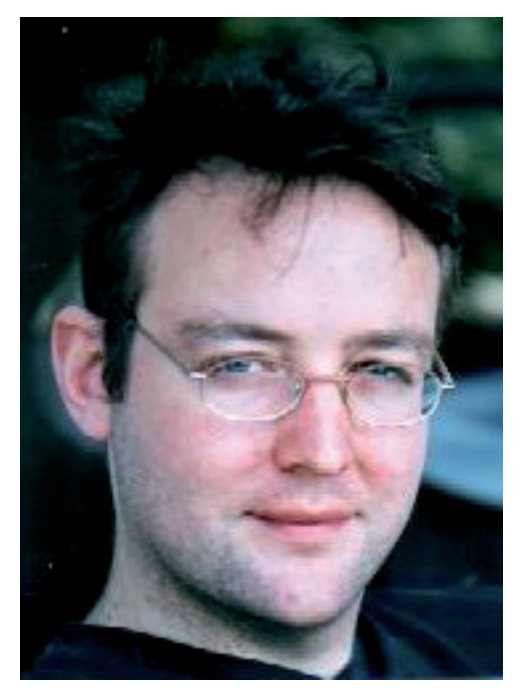

FIGURE 4 Sven Bretfeld

Sven Bretfeld holds the Chair of Religious Studies at the Department of Protestant Theology of Ruhr-University Bochum.

At the Käte Hamburger Kolleg "Dynamics in the History of Religions between Asia and Europe", he contributes expertise on and researches matters related to his research interests. These are focused on the systematics of Religious Studies, intra-religious non-conformity, Indian religious history, Tibetan religious history, Buddhism and Sri Lanka.

As of September 2014, Sven Bretfeld will hold a position at the University of Trondheim (Norway). 


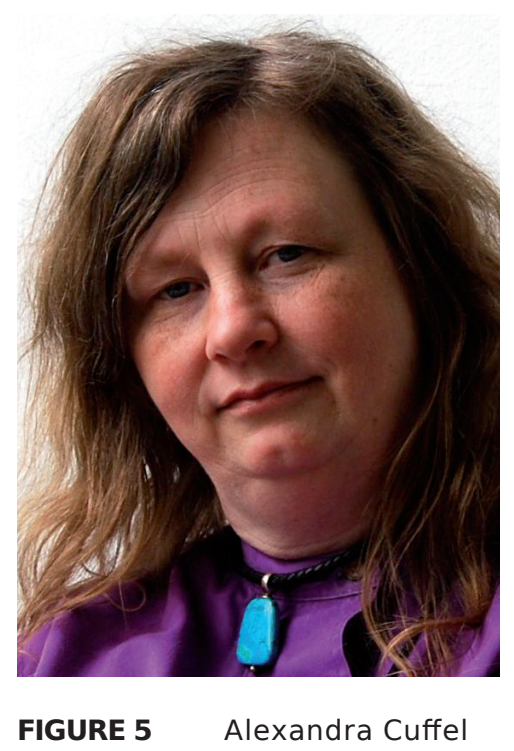

Alexandra Cuffel is professor of Jewish Religion in Past and Present Times at the Center for Religious Studies Research Department (CERES) of RuhrUniversity Bochum.

She received her doctorate from New York University in medieval history in 2002. She has held research fellowships at Harvard Divinity School and the Käte Hamburger Kolleg for the Dynamics in the History of Religions at Ruhr University, and is the recipient of grants from the American Council of Learned Societies and from the German Israeli Foundation.

Her research focuses on relations between Jews, Christians and Muslims during the Middle Ages, specifically on the intersections of religious polemic, medical theories and gender both in Western Europe and the Middle East. Alexandra Cuffel's current research focuses on shared saints' cults and festivals in the medieval and early modern Mediterranean and Jewish, Christian, and Muslim uses of the myth of the ten lost tribes of Israel. 


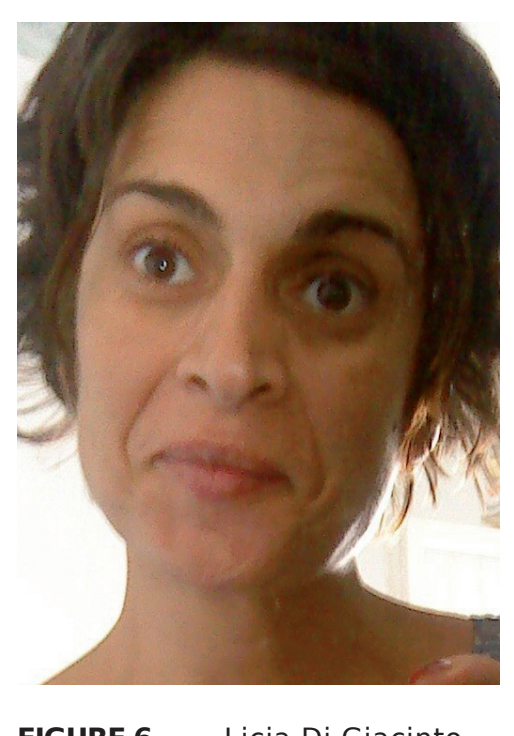

FIGURE 6 Licia Di Giacinto

Licia Di Giacinto is a Postdoctoral Researcher with the Section "History and Philosophy of China" at the Department of East Asian Studies of RuhrUniversity Bochum.

At the Käte Hamburger Kolleg “Dynamics in the History of Religions between Asia and Europe", she contributes expertise on and researches matters related to Sinology. 


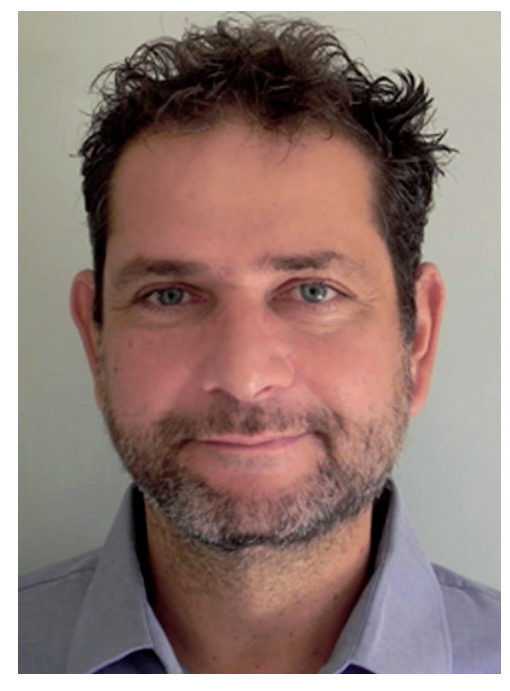

FIGURE 7 Georgios T. Halkias

Georgios Halkias is Assistant Professor of Buddhism at the University of Hong Kong.

His previous affiliations include positions as Adjunct Professor with Antioch University's Buddhist Studies Abroad Program in Bodh Gaya (India), as Visiting Assistant Professor (Hong Kong), as Research Assistant at the Warburg Institute (School of Advanced Studies at the University of London), and as Visiting Research Associate at the Faculty of Oriental Studies at the University of Oxford. A fellow at the Oxford Centre of Buddhist Studies, he has held research fellowships granted by Jōdo Shinsū Otani-ha foundation (Kyoto) and the British Academy at the School of Oriental and African Studies (University of London). In 2009 and 2011, Georgios Halkias held a research fellowship of the Käte Hamburger Kolleg "Dynamics in the History of Religions between Asia and Europe", during which he examined reciprocal exchanges between Hellenism and Buddhism in North-West India and Central Asia.

Georgios Halkias has extensive fieldwork experience in North-West India, Nepal and Tibet. He specializes in Pure Land Buddhism in India, Tibet 
and Central Asia, Tibetan Buddhist rituals, texts and meditative techniques, and the history of religion in imperial Tibet. His research interests extend to religious interactions in the Western Himalayas and Hellenistic Central Asia, and Muslim-Buddhist interactions. (Georgios T. Halkias)

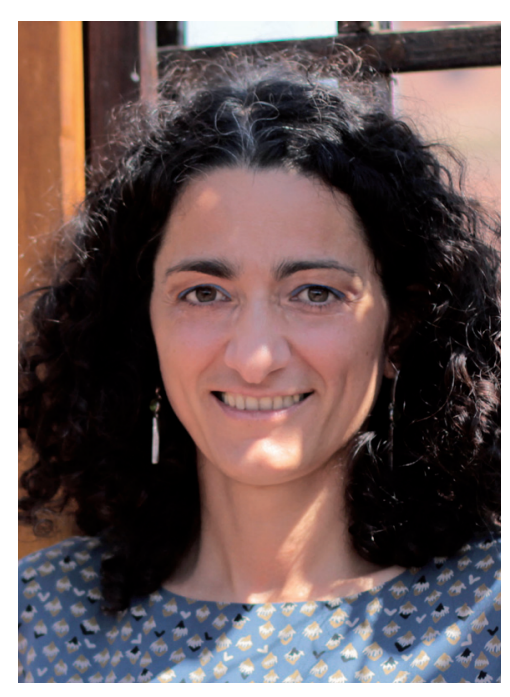

FIGURE 8 Zara Pogossian

Zara Pogossian teaches history and religion at the John Cabot University (Rome) and Loyola University (Rome Center). Her field of specialization is Eastern Christian Churches and their history, with a particular emphasis on the history of Armenia and the Armenian Church during the Middle Ages. Her current research is focused on Armenian apocalyptic traditions and religious polemic and/or dialogue incorporated into these rarely studied texts. Dr. Pogossian is currently preparing a critical edition of an Armenian Apocalyptic text from the VII century known as Agatangel "On the End of the World". In her wider research she has explored female asceticism and ascetic communities in Late Antiquity, the role of women in the spread of 
Christianity in Armenia, monastic establishments and territory control, as well as monasteries in an inter-religious perspective.

Dr. Pogossian is the author of a book (The Letter of Love and Concord, Brill 2011) and numerous articles and book reviews. Pogossian has been the recipient of several prestigious fellowships, such as from the Alexander von Humboldt Foundation, Käte Hamburger Kolleg "Dynamics in the History of Religions between Asia and Europe", and the International Consortium for Research in the Humanities: Fate, Freedom and Prognostication. Strategies for Coping with the Future in East Asia and Europe (University of Erlangen). (Z. Pogossian)

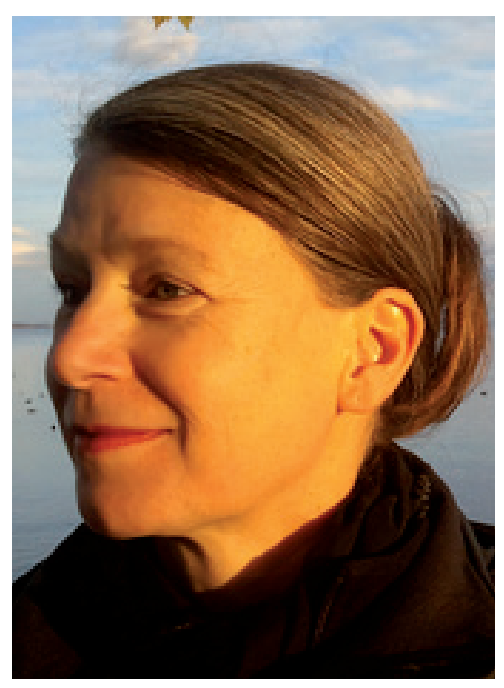

FIGURE 9 Dorothea Weltecke

Since 2007 Dorothea Weltecke holds the Chair for the History of Religions at the University of Constance and is Principal Investigator in the university's Center of Excellence "Cultural Foundations of Integration". From 2001 to 2007 she worked as research associate at the Georg-August-University in 
Göttingen. She received research grants from the "Studienstiftung des Deutschen Volkes", the German Research Foundation, the KHK "Dynamics in the History of Religions between Asia and Europe" and the Institute of Advanced Study in Constance.

Dorothea Weltecke studies the inter and intra-religious dynamics in the history of religions in Europe and the Middle East by following a comparative and integrative approach. She particularly focuses on the centuries between 500 and 1500, the transcultural history of Christianity, the history of religious minorities, religious deviance and religious violence. She published on the history of historiography, Eastern Christianity, and atheism. (D. Weltecke)

Anna Akasoy 